\title{
BREVES REFLEXÕES SOBRE A JURISDIÇÃO ADMINISTRATIVA: UMA PERSPECTIVA DE DIREITO COMPARADO
}

\author{
Romeu Felipe Bacellar Filho*
}

Nosso país, como República, adota, desde a Constituição de 1891, o sistema de Jurisdição única, também denominado de sistema inglês una lex una jurisdictio sem a presença de uma Jurisdição Administrativa. De outro lado, aparece o sistema francês de jurisdição administrativa. Neste último, vigoram duas ordens de jurisdição: a judicial ordinária e a administrativa especializada no julgamento do contencioso administrativo entendido como conjunto das contestações nascidas da atividade administrativa exercida sob o direito administrativo. A peculiaridade, a distinguir ambos sistemas não se assenta apenas na competência especializada, mas também no aspecto jurisdicional. Afinal, os Tribunais Administrativos desenvolvem atividade jurisdicional, todavia, desconectados da hierarquia judicial ordinária. ' Ainda cabe ressaltar a experiência de outros países de uma jurisdição administrativa integrada ao Poder Judiciário.

Para a compreensão das aproximações e distinções de ambos os sistemas (francês e brasileiro) e os problemas atuais sobre o controle judicial da atividade administrativa, faz-se necessário breve histórico sobre o sistema de jurisdição una e o contencioso administrativo.

1 RIVERO, Jean. Direito administrativo. Coimbra: Almedina, 1981. p. 155. No texto, não usaremos a expressāo 'contencioso administrativo' para designar o sistema francês, concordando com a advertência de Marcello CAETANO sobre a vinculaçāo histórica que pesa sobre a expressão, determinando "um preconceito existente em muitos países contra o que se julga ser a subtração autoritária dos atos da Administração ao conhecimento dos juizes ordinários". Como salienta este autor, "é necessário desprender o conceito de contencioso administrativo das origens históricas em França e tratá-lo à luz dos princípios gerais de Direito sine ira ac studio." CAETANO, Marcello. Princípios fundamentais do direito administrativo. Rio de Janeiro: Forense, 1989. p. 491.

* Doutor em Direito do Estado, Professor de Direito Administrativo da Universidade Federal do Paraná, Advogado Militante. 


\section{O sistema francês}

A existência, na França, de uma Jurisdição Administrativa distinta da Jurisdição Judiciária representa produto da história, deitando raizes na concepção de monarquia, sistematizadas neste ponto pela Revolução Francesa e complementadas pelo avanço que, no século XIX, destacou a Jurisdição Administrativa da Administração. Em outras palavras, a Revolução Francesa não inovou quando trouxe a idéia da Jurisdição Administrativa e sim retomou, por sua conta, a herança do Antigo Regime, conferindo aspecto sistemático e colocando-se em prol das concep̧̧ões revolucionárias. ${ }^{2}$

$O$ pensamento nuclear da Revolução, que engendrou a construção da Jurisdição Administrativa, fundamenta-se na idéia de que se os processos administrativos pudessem ser julgados pelos órgãos judiciários, dar-se-ia poder para que estes tumultuassem a atividade administrativa, restando comprometida a independência da Administração. Este raciocínio guardava um sentido histórico inequívoco: o sentimento generalizado de desconfiança em relação ao Poder Judiciário, inspirado na lembrança dos Parlamentos do Antigo Regime. ${ }^{3}$ Para os revolucionários, o Poder Judiciário era um verdadeiro rival do Poder Administrativo. ${ }^{4}$

$\mathrm{O}$ aporte jurídico para a conformação deste pensamento foi realizado por via de uma peculiar interpretação do princípio da separação dos poderes. Como afirma Jean RIVERO, “a jurisdição administrativa nasceu de um princípio interpretado a luz de uma tradição."s

2 Sobre a experiência francesa, no Antigo Regime, ver, sobretudo, André de LAUBADËRE: “A partir do século XVII, muito claramente, assistimos a um reconhecimento das especificidades do contencioso administrativo, compreendido como o solucionar dos litígios com os representantes da administração real. O rei confere a seus intendentes, por meio das cartas de comissão, poderes fortes e vastos para administrar a generalidade que thes é confiada, mas tambem para solucionar os litígios decorrentes de sua própria intervenção. Disto resulta uma situação de conflito entre os Parlamentos, as Cortes de Justiça ordinárias e a jurisdiçảo nascente dos intendentes. O edito de Saint Germain, em 1641, toma firme posição em favor destes últimos declarando que os Parlamentos $e$ as Cortes de Justiça 'foram estabelecidos somente para entregar a justiça aos sujeitos' (os litigios entre as pessoas privadas), e que é expressamente defeso a tais órgãos conhecer em geral das 'matérias que faz julgar por meio dos intendentes'. Esta proibição, feita aos parlamentares de conhecer das matérias administrativas contenciosas, foi repetida inúmeras vezes, $o$ que demonstra que ela não foi admitida sem reações e dificuldades, principalmente pelo Parlamento de Paris. Enquanto isso, paralelamente, precisaram-se e estenderam-se as atribuiçōes contenciosas dos 'intendentes de justiça, de polícia e de finanças', por meio das cartas de comissão. Eles conhecem a maior parte dos contenciosos fiscais, postais, dos litigíos relativos aos militares e aos trabalhadores públicos etc... O Conselho do Rei poderia apoderar-se em apelação. A jurisdiçāo do intendente caracterizava-se, nesta época, por sua gratuidade, sua rapidez e pela ausência de procedimento formalista, dados que se opunham à justiça e contribuíram para o seu sucesso." Trad. por. LAUBADĖRE, André de et al. Traité de droit administratif. 2. ed. Paris: Libraire Générale de Droit et de Jurisprudence, 1992. p. 266. Tome I.

3 O clima revolucionário de desconfiança generalizada no Poder Judiciário não resultou somente na falta de competência para julgar os processos administrativos, mas também na concepção mecânica de swa auaçäo como demonstra 0 art. 5ீ, do Código de Napoleão: "é proibido aos juízes pronunciarem-se pr via de disposiçāo geral e regulamentar sobre as causas que lhes são submetidas."

4 LAUBADËRE et al., Traité..., op. cit., p. 267.

5 "O princípio é o da separação dos poderes, aplicado is relaçōes entre o Judicial e o Executivo: para salvaguardar a liberdade dos cidadãos 'o poder de julgar' deve, segundo Montesquieu, ser separado do 
A evolução do sistema francês atravessou diversas etapas. Não cabe o exame detalhado, todavia, salientar períodos cruciais. A primeira expressão legislativa da Revolução foi a célebre Lei de $n^{2} 16$, de 24 de agosto de 1790: "As funções estatais estão e sempre permanecerão separadas das funções administrativas. Os juízes não poderão, sob pena de prevaricação, obstaculizar de qualquer maneira as operações dos corpos administrativos nem citar os administradores em razão de suas funçōes."

As Leis de $n^{2} 7$, de outubro e a Lei $n^{2} 6$, de 11 de setembro de 1790 criaram o sistema de "administração-juiz", que consistiu em confiar o contencioso administrativo aos órgãos da própria Administração, no caso: o rei, ministros e administradores de departamentos. Em nome da separação dos poderes, uma parte da função de julgar foi conferida às autoridades administrativas. Mas idéia de um mesmo órgão como juiz e parte terminou por ser rejeitada. ${ }^{6}$

A separação da Administração ativa da julgadora importou marco de uma nova era. A Lei de 24 de maio de 1872 consagrou esta evolução instituindo, definitivamente, para o Conselho de Estado a justiça delegada (a qual já havia funcionado, episodicamente, de 1848 a 1852). A partir de então, o Conselho de Estado, regulamentando o contencioso, resolve, por si só, os litígios, sem intervenção do Chefe de Estado. Ao mesmo tempo, sendo organizado um Tribunal de conflitos de competência que, porventura, surgissem entre a Jurisdição Administrativa e a Judiciária.'

A distinção definitiva entre Justiça administrativa e Administração ativa sobreveio em aresto de 13.12.1889 (Julgamento Cadot). Nesta ocasião, o Conselho de Estado suprimiu a jurisdição ordinária de primeiro grau do Ministro, deixando de funcionar como Corte de Apelação. É certo que a teoria do "Ministro-Julgador"

'poder executante'. Mas como aplicar o princípio ao julgamento dos litígios nos quais o 'poder executante' está comprometido, ou seja, no contencioso administrativo? Trata-se de julgar: isto pode levar a confiá-los ao poder judicial ordinário; trata-se de julgar o Executivo: isto pode conduzir a subtrair-lhos, na medida em que ao julgá-los corre o risco de imiscuir-se na acção do Executivo. Pode-se pois, a partir do princípio da separação dos poderes, optar com igual lógica por uma ou por outra soluçāo. O que dita a opção dos homens de 1789 é a tradiçāo. O Ancien Régime conheceu tribunais especializados nas matérias administrativas (corte dos auxflios, câmara de contas, tribunais de águas e florestas). Sobretudo viu o conflito quase permanente entre os parlamentos e a administração real: para vencer as resistências levantadas pelos parlamentares, o rei chamava ao seu conselho, ou fazia julgar pelos seus comissários, principalmente pelos intendentes, um grande número de casos administrativos. Os revolucionários temem que os corpos judiciários retomem, no que toca à nova Administração, a tradiçăo de ingerência e de oposiçăo dos parlamentos. E por isso que fazem derivar do princípio da separação dos poderes a proibição de o judicial estatuir sobre os litígios em que a administração está em causa. RIVERO, Jean. Direito Administrativo. Coimbra: Almedina, 1981. p. 157-158. Nesse sentido, também André de LAUBADËRE: “este estado de ánimo antijudicial fue el que, bajo la Revolución, hizo interpretar el principio de la separación de los poderes como si exigiera, a nombre de la independencia de la administración para los tribunales ordinários de juzgar los procesos administrativos." LAUBADËRE, Manual..., op. cit., p. 36.

6 LAUBADËE, Manual..., op. cit., p. 37.

7 “A evoluçāo do sistema francês passou por diversas etapas. Talvez a mais importante tenha sido aquela que se esboçou no seio da administração, uma nova separaçāo entre a função ativa $e$ a função juriadicional, que é preciso distinguir bem da separação de poderes: esta interessa às relaçōes entre o executivo e o judiciário, enquanto a separaç̧o das funçōes só diz respeito à divisão do trabalho no seio do executivo, certos agentes deste especializando-se no julgamento do contencioso. É desta separação de funçōes que assceu a jurisdiçāo administrativa." GOMES DA CRUZ, op. cit., p. 172. 
minimizou a reforma do ano VIII à medida que manteve o Juiz administrativo de direito comum como representante da Administração ativa e fez dos Tribunais, recentemente criados, Cortes de Apelação.

Com a Lei de 24 de maio de 1872 e a interpretação conferida pelo Conselho de Estado no aresto citado anteriormente, o sistema francês adquire o contorno de jurisdição administrativa, que o caracteriza até hoje: ao lado do princípio da separação das autoridades administrativa e judiciária, adiciona-se a separação da Administração ativa e contenciosa. ${ }^{8}$

Entretanto, as Constituições francesas modernas não retomaram a tradição da Revolução. Nem a Constituição de 27 de outubro de 1946, nem a atual, de 4 de outubro de 1958, mencionam a existência de uma jurisdição administrativa, ao lado das disposições consagradoras do arquétipo da judiciária. $O$ art. 37 da Constituição de 1958 cita o Conselho de Estado a título de suas funções consultivas.

A par da falta de referência expressa na Constituição, o Conselho Constitucional afirmou, recentemente, a propósito de um texto legal transferindo o contencioso das decisões do Conselho da Concorrência (autoridade administrativa) aos Tribunais de ordem jurisdicional, a existência de um princípio fundamental reconhecido pelas Leis da República, com valor constitucional, que estabelece a Jurisdição Administrativa ao lado da judiciária, além de uma competência constitucionalmente reservada à primeira. Os principais motivos desta divisão foram retomados pelo Conselho Constitucional no julgamento de uma lei sobre controle de estrangeiros. ${ }^{y}$

O princípio constitucional, afirmado pelo Conselho Constitucional, é de que este decide com valor constitucional "a competência da jurisdição administrativa para anulação ou reforma das decisões tomadas, dentro do exercício das prerrogativas do poder público, pelas autoridades exercentes do Poder Executivo, seus agentes, as coletividades territoriais da República e os organismos públicos colocados sob a sua autoridade ou controle"."

A competência própria, constitucionalmente reservada à Jurisdição Administrativa, está, claramente, mais reduzida que sua esfera de competência. $O$ vasto campo do contencioso pleno que lhe é exterior, e no interior mesmo do contencioso de excesso de poder, as transmissões podem intervir em benefício da Corte Judiciária, sob as condições já explicitadas. O legislador conserva, assim, grande liberdade de ação, a qual ele inclusive já usou no passado, notadamente transferindo ao Tribunal Judiciário uma parte considerável do contencioso de responsabilidade da Administração."

8 LAUBADÈRE, André et al., op. cit., p. 268. Este momento marca a definitiva evoluçāo do sistema de 'justicia retenida' ao sistema de 'justicia delegada'. Carlos GARCIA OVIEDO afirma que no sistema de 'justicia retenida', a própria Administração tem a faculdade de resolver os litígios. Quem decide é o Poder Executivo sistema do 'ministro-juez 'e a intervenção de outros órgãos é meramente consultiva. No modelo de 'justicia delegada', a Administração delega esta funçāo a certos organismos formados com elementos de seu próprio seio, mas reconhecendo sua independência. OVIEDO, op. cit., p. 494.

9 LAUBADÈRE et al., Traité..., op. cit., p. 269.

10 LAUBADÈRE et al., Traité..., op. cit., p. 269.

11 LAUBADÈRE et al., Traité..., op. cit., p. 270. 
No Brasil Colônia houve uma pálida tentativa de instituição do sistema de contencioso administrativo, porém desprovido do caráter de entidade jurisdicional. $O$ art. 142 da Constituição de 1824 , com a redação resultante do art. $7^{\circ}$, da Lei de 23.11.1841 dispunha:

"Incumbe às seç̧ões ou ao conselho de estado de dar seu parecer ou consulta sobre todos os negócios em que o imperador houver por bem ouvi-lo e especialmente sobre [...] assumptos de natureza quasi contenciosa, como questōes de presas, de indemnizações, conflictos entre as autoridades administrativas, e entre estas e as judiciarias, e abusos das autoridades eclesiásticas [...] negocios de justiça administrativa contenciosa." 12

O Conselho de Estado, órgāo integrado à Administração, detinha a função consultiva nas matérias de contencioso administrativo. Segundo Marcello CAETANO:

“[...] No Brasil do tempo da independência a Administração imperial, que era a coluna dorsal do Estado e que defrontava os problemas do desenvolvimento de vastíssimo território, estava mais preocupada com a eficácia do que com a legalidade. Os recursos administrativos não chegavam a oferecer no século XIX um princípio de garantia contra os atos irregulares das autoridades." 13

Eduardo LOBO BOTELHO GUALAZZI comenta que "no máximo, tivemos no Brasil Império um arremedo de justiça administrativa, alheia ao Poder Judiciário, mas totalmente dependente da Administração ativa, na qual se inseria e a que se subordinava por texto legal expresso e claro." 14

A Constituição de 1891 fixou o sistema de jurisdição una, inspirada na experiência norte-americana ao lado da República e do federalismo. Os Tribunais Judiciários aparecem, aqui, como os órgãos tutelares dos direitos individuais. Como salienta Marcello CAETANO:

A adoção do sistema federativo, com a proclamação da República, em 1889, levou os brasileiros a olhar com mais atenção as instituições jurídicas norte-americanas. O judicialismo da Constituição Brasileira de 1891 tinha de evoluir no sentido do controle da legalidade administrativa pelos tribunais comuns. Mas a única instituição correspondente aos writs prerrogativa da common law era então habeas

12 GOMES DA CRUZ, José Raimundo. $O$ controle jurisdicional do processo disciplinar. São Paulo: Malheiros, 1996. p. 242.

13 CAETANO, Marcello. As garantias jurisdicionais dos administrados no direito comparado de Portugal e do Brasil. Revista de Direito Administrativo, Rio de Janeiro, Seleçāo Histórica, p. 427, 1996.

14 GUALAZZI, Eduardo Lobo Botelho. Justiça administrativa. São Paulo: Revista dos Tribunais, 1986. p. 140. O autor acrescenta: "Com efeito, o Imperador sempre pode rever e alterar as decisōes do Conselho de Estado sobre matéria contenciosa administrativa, situação que recorda a daqueles dez anos (1789-1799) em que a França conheceu ofenômeno da administraçāo-juiz (funcionários da administração ativa é que julgavam litígios administrativos), bem como relembra, mutatis mutantis, a do perfodo francês inaugurado pelo Imperador Napoleão Bonaparte, no tocante à "justiça retida'". 
corpus. E foi através deste que se ensaiou a intervenção dos tribunais na defesa dos direitos dos indivíduos, ameaçados ou violados por atos ilegais da Administração. ${ }^{15}$

A Constituição de 1967, com a Emenda n² 1, de 1969, dispôs no art. 153, § 4², que "A Lei não poderá excluir da apreciação do Poder Judiciário qualquer lesão de direito individual." Contudo, o art. 111, veio ensejar sérias dúvidas ao estabelecer que a Lei poderia "criar contencioso administrativo e atribuir-lhe competência para o julgamento das causas mencionadas no artigo anterior". $O$ art. 110 , por sua vez, estipulou que "os litígios decorrentes das relações de trabalho dos servidores com a União, inclusive as autarquias e as empresas públicas federais, qualquer que seja o seu regime jurídico, processar-se-ão e julgar-se-ão perante os juízes federais, devendo ser interposto recurso, se couber, para o Tribunal Federal de Recursos." Houve entendimento no sentido de que estes artigos atribuíam a órgãos administrativos a decisão sobre os mencionados litígios, com força de julgamento. ${ }^{16}$ No entanto, este órgão administrativo não chegou a ser criado, uma vez que inexistiu regulamentação da regra constitucional e ainda que o fosse, suas decisões não operariam força de coisa julgada, diante da previsão da competência do Tribunal Federal de Recursos, confirmando o preceituado no art. $153, \S 44^{2}$.

A Constituição Federal de 1988 , no art. $5^{\circ}$, inc. XXXV, estabeleceu que "a lei não excluirá da apreciação do Poder Judiciário lesão ou ameaça a direito." Afirmada, no texto constitucional, a supremacia do Poder Judiciário, excluiu-se a possibilidade da instituição de uma Jurisdição Administrativa independente, tal como ocorre nos países que adotam o modelo francês. ${ }^{17}$

Em contrapartida, a vigente Constituição expandiu o campo de controle da atividade administrativa pelo Poder Judiciário, de um lado, mediante a criação de novas ações constitucionais (habeas data, mandado de segurança coletivo, mandado de injunção) e reforçamento das já existentes (ação popular e ação civil pública) e, de outro, pela expressa afirmação de princípios constitucionais da Administração Pública (legalidade, moralidade, impessoalidade e publicidade).

Nesse diapasão, concorde-se com José Raimundo GOMES DA CRUZ na assertiva de que, no período republicano, antes da Constituição de 1988, e mesmo após iniciada sua vigência, tem o Brasil adotado o sistema de jurisdição una. ${ }^{18}$

\section{Tendências na evolução da jurisdição administrativa e seu significado prático}

$O$ debate sobre a funcionalidade prática de uma jurisdição una ou dúplice, no que tange à estrutura de uma típica jurisdição administrativa, é tema de atualidade,

15 CAETANO, As garantias..., op. cit., p. 426.

16 GOMES DA CRUZ, op. cit., p. 253.

17 Para José Sebastião FAGUNDES CUNHA, o dispositivo constitucional em questão assegura a igualdade perante a justiça, permitindo a todos o acesso ao Poder Judiciário para a soluçāo de seus problemas jurídicos, embora nāo afaste a situaçāo de desigualdade que ocorre entre os mais favorecidos economicamente e aqueles carentes de recursos. CUNHA, José Sebastião Fagundes. Recursos de impugnaçāo nos juizados especiais civeis. Curitiba: Juruá, 1996. p. 30.

18 GOMES DA CRUZ, op. cit., p. 200. 
dado o fenômeno mundial do aumento da ingerência da máquina administrativa no cotidiano de cada cidadão.

No sistema francês de jurisdição administrativa, o tema coloca-se em face do desaparecimento da desconfiança em relação ao Judiciário, fundamento da interpretação francesa do princípio da separação dos poderes. Logo, se o sistema manteve-se mesmo dissipada sua razão de ser original, é porque outras razões devem ser suscitadas.

O debate atual não mais se posiciona em termos de fundamentos teóricos: a história comprovou a possibilidade de interpretações diferenciadas a respeito da independência dos poderes estatais sem a quebra do núcleo essencial. ${ }^{19}$ Antes, trata-se de discutir problemas práticos: qual o modelo de jurisdição é capaz de oferecer maior possibilidade de uma justiça satisfatória entre Administração e cidadãos, assegurando uma efetiva proteção destes em relação àquela?

No Brasil, a criação constitucional dos Juizados Especiais é uma das amostras mais contundentes da preocupação com a efetividade da justiça. No Direito Administrativo, a questão ganha contornos mais delicados devido ao aumento da complexidade das normas administrativas. Uma justiça que se queira célebre e eficiente necessita estar dotada de conhecimentos técnicos da realidade administrativa.

Nesta perspectiva, cabe analisar os sistemas (francês e brasileiro) sob o ponto de vista da proteção dos cidadãos e das garantias de suas liberdades diante do poder da Administração, bem como da simplicidade e comodidade prática para o cidadão.

No sistema francês, a existência de uma Jurisdição Administrativa garante aos cidadãos (e à Administração) julgadores com experiência na resolução dos conflitos administrativos. Em contrapartida, a presença de uma jurisdição especial para a Administração pode ser encarada como um privilégio que conduz à formação de um direito de exceção. Destarte, a crítica dos anglo-saxões a esse sistema reflete a preocupação com a eficiência da limitação do poder da Administração através de um órgão que a integra. A esta crítica, adiciona-se àquela relacionada ao princípio da igualdade entre poder público e cidadão.

$O$ rebate da doutrina francesa vem no argumento de que os Tribunais Administrativos não guardam como missão a defesa das prerrogativas da Administração. Além de separados da Administração ativa, o Conselho de Estado alicerçou, historicamente, jurisprudência no sentido de amplo controle dos atos administrativos, especialmente, através dos recursos de excesso de poder. ${ }^{20}$

Do ponto de vista da simplicidade e comodidade prática do jurisdicionado, é certo que a dualidade de jurisdições apresenta o problema grave da incerteza quanto à competência de cada uma, ainda mais tendo-se em mente o aumento da ingerência

19 No sistema anglo-saxão, a independência entre os Poderes Judicial e Executivo exigiu a formação de uma jurisdição, de parte do Judiciário, para resolução dos conflitos administrativos à medida que o fato da Administraçāo ser julgada por um juiz judicial nāo compromete sua independência, entendendo-se que o papel do juiz reside, unicamente, no de declarar o direito em um processo. No sistema francês, por sua vez, o controle judicial da Administraçāo foi encarado como forma de burlar a independência desta última. LAUBADERE, Manual..., op. cit., p. 36.

20 LAUBADĖRE et al., Traité..., op. cit., p. 274. 
estatal, como referido. Mesmo na França, o berço do sistema de jurisdição dúplice, a divisão de competência é matéria complexa e controvertida. Como salienta Jean RIVERO, “a dualidade de jurisdições apresenta inconvenientes manifestos. É muitas vezes difícil saber se uma questão deve ser apresentada perante os Tribunais administrativos ou ordinários, daí os atrasos e as dificuldades que os recorrentes têm de suportar." 21

A experiência dos outros países europeus caminha para a superação de dois problemas do sistema francês: a dificuldade em conciliar uma jurisdição una com a especificidade dos juízes e a falta de constitucionalização da Jurisdição Administrativa, embora a sua existência esteja afirmada pelo Conselho Constitucional como princípio de valor constitucional.

\section{Movimento de constitucionalização da jurisdição administrativa}

Excetuando-se a Grã-Bretanha e a Irlanda, a maior parte dos países europeus esteve, durante muito tempo, influenciada pelo modelo francês. ${ }^{22}$ Durante o século XX, não obstante, muitos Estados europeus melhoraram a organização do contencioso de forma autônoma. Os principais elementos desta evolução foram a constitucionalização do Estatuto da Justiça Administrativa, a integração das Jurisdições Administrativas ao Poder Judiciário e a aproximação entre o procedimento das Jurisdições Civis e aquele das Jurisdições Administrativas. Contudo, a lógica das instituições impôs maior passo: a proteção do cidadão frente à Administração foi alçada a título de direito fundamental.

Naquele continente, a idéia de que a proteção jurisdicional contra a Administração deva ser garantida pela Constituição teve seus primeiros delineamentos muito cedo. A Constituição do Reich Alemão, em 1849, deixava transparecer esta intenção. Porém, o primeiro precedente configurou-se na Lei Fundamental sobre o Poder Judiciário, promulgada em 21 de dezembro de 1867, para a nova Áustria-Hungria. ${ }^{23}$

Com o desenvolvimento da Justiça Constitucional e do controle da constitucionalidade, após a Segunda Guerra Mundial, a constitucionalização da Justiça Administrativa sofreu progressos decisivos. Nasceram, assim, as primeiras Constituições Européias a consagrarem dispositivos limitadores da Administração. Dentre elas,

21 RIVERO, op. cit., p. 161. Salientando este mesmo problema, LAUBADÈRE et al., Traité..., op. cit., p. 275.

22 Sobre uma apurada análise da experiência francesa e européia, ver, sobretudo, FROMONT, Michel. La justice administrative en europe convergences. In: CHAPUS, René et al. Droit administratif. Paris: Montchrestien, 1992. p. 197.

$23 \mathrm{O}$ art. 15 daquele documento ordenava: “No caso onde uma autoridade administrativa decidir segundo a lei sobre os direitos opostos de pessoas privadas, a pessoa que é prejudicada por tal decisão em seus direitos, pode procurar obter uma indenização em face de outra pessoa perante os Tribunais civis. Quando, de outro lado, alguém sente-se prejudicado em seus direitos por uma decisão da autoridade administrativa, deve fazer valer seus direitos perante a Corte da Justiça Administrativa, segundo um procedimento público contra um representante da autoridade administrativa." FROMONT, op. cit., p. 198. 
podemos arrolar a Constituição Italiana de 1948 que, no art. 113, dispõe: "Contra os atos da Administração Pública, a proteção jurisdicional dos direitos e interesses legítimos perante os órgãos da jurisdição ordinária e administrativa é sempre garantida. Esta proteção jurisdicional não pode ser excluída nem limitada a alguns tipos particulares de recursos ou a categorias determinadas de atos."

O exemplo italiano foi imediatamente seguido pela República Federal da Alemanha, onde a Lei Fundamental de Bonn, em 1949, dispôs, em seu art. 19, alínea 4: "Toda pessoa lesada em seus direitos pela potência pública dispõe de um recurso jurisdicional".

O movimento de constitucionalização do princípio de proteção dos indivíduos frente à Administração conheceu, em seus últimos anos, um prolongamento espetacular na jurisprudência da Comissão e da Corte Européia dos Direitos do Homem que passaram a interpretar, a partir de 1985, o princípio do juiz legal, disposto no art. $6^{2}$ da Convenção, como garantidor do direito de todas as pessoas perante um Tribunal independente e imparcial na proteção em face de uma Administração que ofende, ilegalmente, um direito assemelhado a um direito civil (seja um direito de caracteríisticas patrimoniais direito de propriedade, seguridade social, pensōes ou um direito profissional)..$^{24}$

Como se pode notar, o sistema francês apresenta sérios obstáculos para progredir neste sentido, já que o Estatuto Constitucional da Jurisdição Administrativa não integra o texto constitucional, mas tão-somente a jurisprudência do Conselho Constitucional. Para Jean RIVERO, o sistema francês progride, justamente, para a separação cada vez mais profunda entre Administração ativa e Jurisdição Administrativa, e, concomitantemente, a uma aproximação entre esta e a Jurisdição Ordinária. ${ }^{25}$

Nos demais países europeus, a aproximação entre Jurisdição Administrativa e Ordinária é mais evidente à medida que a Justiça Administrativa tende a ser considerada parte do Poder Judiciário. Tal tendência tornou-se, após o início da segunda metade deste século, patente. A vontade de romperem com as ditaduras passadas explica que os principais países a tomarem tal direção tenham sido Itália, Alemanha, Grécia e Portugal. Almejavam os elaboradores constitucionais, em graus diversos, reforçar as garantias de independência e o prestígio social das Jurisdições Administrativas, integrando-as, de modo mais ou menos evidente, ao Poder Judiciário. Cada vez mais, percebe-se que a organização e o procedimento dos órgãos da Jurisdição Administrativa estão próximos dos órgãos da Jurisdição Civil. ${ }^{26}$

A Constituição Espanhola de 1978 consagra a unidade do Poder Judiciário, quando no art. 117, alínea 5, afirma: "O princípio da unidade da jurisdição está na base da organização e do funcionamento dos Tribunais", disposição confirmada pelo art. 123, alínea 1: "O Tribunal Supremo, do qual a jurisdição estende-se a toda Espanha, é o órgão jurisdicional superior em todas as ordens, salvo disposições em matéria de garantia constitucional." Deste modo, está alcançada a conciliação das 
duas exigências que são consideradas, pelos franceses, como incompatíveis entre si: a unidade de jurisdição e a especialização dos juízes.

Portugal adotou o sistema francês temperado pela autonomia municipal proveniente de sua tradição, dispondo, entretanto, sobre o Estatuto Constitucional da Jurisdição Administrativa no art. 211, da Constituição de 1976. ${ }^{27}$

Aparentemente, a França mantém-se à parte da presente movimentação ocorrida em diversos países europeus. Entretanto, mesmo neste domínio, ela já promove alguns passos tímidos, como mostra a decisão $n^{2} 80.199$, D. C. de 22 de julho de 1980, onde o Conselho Constitucional afirmou o princípio da independência de todas as jurisdições, sejam administrativas ou judiciárias. ${ }^{28}$

\section{Movimento de aproximação das jurisdições}

Como já apontado, a aproximação entre a Jurisdição Judiciária e a Administrativa, proclamado por várias Constituições Européias, tem por objetivo a proteção do cidadão em face da Administração. Mesmo nos países que não adotaram, irrestritamente, a integração da Justiça Administrativa ao Poder Judiciário observa-se uma inclinação ao reforço das exigências do conhecimento do Direito Administrativo por parte dos juízes e, sobretudo, maior reconhecimento da garantia de independência destas instâncias julgadoras.

Desenvolve-se, na Europa, as técnicas de decisão privilegiadoras do efeito suspensivo dos recursos dirigidos contra as decisões da Administração e dos procedimentos de urgência em nome da igualdade entre as partes. Os poderes de decisão dos juízes pendem para o progressivo aumento, não estando mais limitados à simples cassação da decisão administrativa contestada, vestígio longínquo da antiga idéia da autoridade administrativa como uma espécie de juiz de primeira instância e a Corte Administrativa como superior hierárquico dotada de poderes limitados.

A realidade européia pauta-se pela presença de uma Jurisdição Administrativa orientada para proteção da legalidade e correição das relaçōes entre Administração e cidadão.

\section{Inserção do sistema brasileiro nas tendências européias}

Como salientado, a proteção do cidadão perante a Administração representa, na

27 Segundo Marcello CAETANO, “Os Tribunais Administrativos apareceram em consequiência da evolução do recurso hierárquico jurisdicionalizado. Por isso esses tribunais se integram na Administração onde figuram como órgãos superiores independentes, aos quais está confiado o 'controle' da legalidade dos atos administrativos. Nāo são, pois, meros tribunais judiciais de competência especial: mas órgãos jurisdicionais da Administração que se limitam a controlar a legalidade do procedimento das autoridades para manter ou anular os atos recorridos. Todavia, a isenção com que julgam e o respeito voltado às suas sentenças criaram a confiança na justiça e consolidaram a sua existência." CAETANO, As garantias..., op. cit., p. 427.

28 FROMONT, op. cit., p. 204. 
atualidade, o leit motiv da organização de um sistema de competências a partir de um Estatuto Constitucional da Jurisdição Administrativa. Se, historicamente, a razão original concentrava-se na perspectiva do Estado - visando a construção de um sistema garantidor da independência entre os poderes - , hoje o enfoque parte muito mais do cidadão. ${ }^{29}$

Mostrou-se, até aqui, que a segunda metade do século $\mathrm{XX}$ foi marcada por uma evolução considerável na realidade européia: a Jurisdição Administrativa tem sido objeto de consagração constitucional, integrando-se, cada vez mais, ao Poder Judiciário, a par da necessidade de especialização dos juízes.

A tradição brasileira é a jurisdição una. O problema do abuso do poder por parte da Administração resolveu-se pelo controle da constitucionalidade ao passo que, na França, pelo contencioso administrativo. Consistem em duas perspectivas diversas: uma em favor do Poder Judiciário como árbitro dos conflitos políticos, a outra contra aquele. Ainda assim, a questão de uma justiça especializada na resolução dos conflitos administrativos não passou despercebida pela nossa doutrina. No solo pátrio, Manoel de OLIVEIRA FRANCO SOBRINHO foi o precursor da defesa de uma Jurisdição Administrativa como anteparo de proteção do cidadão. ${ }^{30}$

A Constituição de 1988, conforme aludido, aumentou o poder de controle do Judiciário ao elastecer o princípio da inafastabilidade do Poder Judiciário, no art. $5^{\circ}$, inc. XXXV, onde à expressão "lesão" acrescentou-se "ameaça" e foi suprimido o termo "individual" relativos aos direitos, para alcançar quaisquer direitos (individuais, coletivos, difusos). Concede-se, desta forma, um poder geral ao Poder Judiciário, inserido na tendência de aumento do espectro protetivo do controle jurisdicional, materializado pela ampla possibilidade de reexame das decisões da Administração. $A$ isto, acrescente-se a afirmação constitucional da jurisdição constitucional.

A independência da Administração, frente ao Poder Judiciário, sempre esteve assegurada através do escudo do "mérito do ato administrativo", delimitando um campo de atuação próprio, sem ingerência deste. A par da sólida construção doutrinária, expressas referências legislativas vigoram, como é o caso da Lei disciplinadora do mandado de segurança (Lei 1.533, de 31 de dezembro de 1951).

29 Com isto, não queremos dizer que o problema do relacionamento harmônico entre os Poderes tenha deixado de orientar o sistema, mas tão-somente que, superado os problemas principais que a questão despertava, passa-se agora para a pauta da eficácia da organizaçāo do sistema de competências. Mesmo o princípio da separação dos poderes pode ser analisado sob esta perspectiva. Com base na lição do jurista americano Burt NEUBORNE, tem-se que a teoria da separação negativa (negative separation) vê o poder governamental como uma bomba e reparte-se a fórmula da bomba entre uma série de funcionários públicos. O método está em impedir que mais de uma das três funçōes concentre-se em um só poder e a finalidade central reside na prevenção da tirania. De outro lado, a teoria da separação positiva (positive separation) prevê a designação das funções ao órgão mais equipado. A finalidade central encontra-se no atingimento da eficácia. Burt NEUBORNE comenta que estas duas teorias estão protegidas pela Consti-

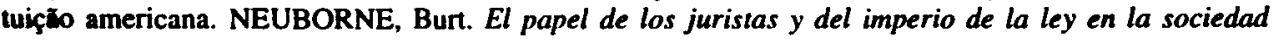
americana. Madrid: Cuadernos Civitas, 1995. P. 37-38.

30 FRANCO SOBRINHO, Manoel de Oliveira. Curso de direito administrativo. São Paulo: Saraiva, 1979. 
No mesmo texto legal, vigora outra regra que merece referência; a do esgotamento da via administrativa para o uso da judicial. Estabelece a mesma que não cabe mandado de segurança "de ato que caiba recurso administrativo com efeito suspensivo, independente de caução". Impedida está, por conseguinte, a provocação do Judiciário antes de exaurida a manifestação recursal administrativa, a qual foi outorgado o efeito suspensivo. A razão é marcada de obviedade: a interposição de recurso administrativo recebido pela autoridade competente, em razão legal, com efeito suspensivo, faz desaparecer, ainda que momentaneamente, a ofensa ou o constrangimento a direito líquido e certo. Imprescindível, porém, que a autoridade a quem o recurso seja dirigido, sem se omitir, efetivamente receba-o com tal efeito, pois, no caso inverso, tem plena aplicabilidade a Súmula $\mathrm{n}^{\mathrm{Q}} .429$ do S.T.F., verbis: "A existência de recurso com efeito suspensivo não impede o uso do mandado contra omissão de autoridade." 31

A Lei no 1.533 de 1951, no artigo 5․, inciso III, estabelece o não cabimento de mandado de segurança contra "ato disciplinar, salvo quando praticado por autoridade incompetente ou com inobservância de solenidade essencial”. Aqui, fixa-se o campo do controle da legalidade do ato administrativo. ${ }^{32}$

Vigora, no Brasil, situação diversa da encontrada nos demais países. Diante disso, foi exata a colocação de Carlos Alberto Álvaro de OLIVEIRA de que não devamos apenas inovar por inovar, mas devamos objetivar a construção de um sistema compatível com a realidade aqui vigente. ${ }^{33}$

No intuito de implantar uma Jurisdição Administrativa, não há necessidade de nos afastarmos da nossa tradição judicialista, onde os Tribunais com poderes para proferir decisões, com força de coisa julgada, encontram-se integrados ao Poder Judiciário. Esta é, ao fim, a tendência européia: a formação de uma jurisdição administrativa, com Estatuto Constitucional, integrada ao Poder Judiciário.

A criativa transformação do ordenamento judiciário processual depende de não perdermos de vista as garantias preteritamente adquiridas pelo cidadão, oferecendo

31 'É comum aos writs e ao sistema administrativo português o fato do 'controle' jurisdicional incidir sobre atos. Não são as pessoas que são julgadas (como os remédios ordinários da Common Law, ou nas ações tendentes a efetivar a responsabilidade civil do Estado ou dos funcionários, existentes no Direito Português ou Brasileiro): trata-se unicamente de verificar se 0 ato violador dos direitos é ou não legal. Esse ato só pode ser submetido aos tribunais portugueses, como aos brasileiros, depois de estarem esgotados os meios graciosos de discussão administrativa. É a regra que, no Direito norte-americano, denomina-se exhaustion of administrative remedies." CAETANO, As Garantias..., op. cit., p. 428.

32 Entendida a competência como a parcela de poder atribuída, pela lei, ao agente para a prática do ato, fica claro que, quando o ato por si praticado, não se encontre em seu rol legal de atribuiçōes, torna-se viciado por incompetência que, no caso, conforme já visto, poderá ser confundido com o abuso de poder, na modalidade do excesso de poder. Um ato disciplinar, por tal modo praticado, submete-se ao controle judicial em sede de mandado de segurança. De igual modo, a inobservância de formalidade essencial, também viabiliza o uso do mandado de segurança, eis que a forma, correspondendo ao modo como o ato ou o procedimento administrativo vem externado, tem a sua liturgia preestabelecida em lei. Logo, qualquer inobservância, viciando o proceder administrativo, acende o estopim da ação mandamental.

33 OLIVEIRA, Carlos Alberto Álvaro. Jurisdição e Administração. Separata da Revista de Informação Legislativa, Brasília, n. 119, jul./set. 1993. 
maior celeridade à prestação jurisdicional. As causas determinantes de uma justiça lenta, ineficiente e avolumada de processos necessitam ser, melhor e seriamente, avaliadas. A usual e vetusta fórmula de ampliar o número de juízes, de varas e comarcas, de há muito não responde pelo crescimento geométrico das demandas.

Mantendo a unidade da Jurisdição, propõe-se a instituição de varas e câmaras integradas à estrutura do Poder Judiciário, especializadas no julgamento da matéria administrativa. De igual sorte, a criação de Juizados Especiais, como proposto pela Constituição Federal, em seu artigo 98, inc. I, para conciliação (dentro dos limites legalmente conferidos aos procuradores da Fazenda Pública), julgamento e execução de litígios cíveis-administrativos de menos complexidade da competência dos juízes federais e estaduais (imposição de multas, por exemplo).

De lege ferenda, defende-se que a proteção do cidadão frente à Administração deve caminhar para a criação constitucional de uma Jurisdição Administrativa integrada ao Poder Judiciário. Propōe-se a implementação do judicialismo brasileiro para um "judicialismo perfeito" ${ }^{34}$ Com efeito, o processo administrativo conservará uma certa originalidade, todavia, obedecerá a regras que não terão mais por efeito e objeto proteger a Administração, mas assegurar um novo equilíbrio entre Administração e cidadãos. O presente movimento nada mais é do que o equilíbrio dos poderes em proveito da justiça, já que inexiste liberdade quando o direito é desrespeitado.

34 A expressão "judicialismo perfeito" é de Marcelo CAETANO. O autor explica que, no judicialismo perfeito, o Poder Judiciário tem competência para conhecer e julgar as questð̋es administrativas contenciosas, embora o sistema comporte a especializaçāo de tribunais administrativos. De outro lado, as decisōes dos órgāos administrativos estão sujeitas ao controle jurisdicional, onde os juízes podem emitir ordens ou mandatos vinculantes como resultados do processo. Logo "os órgāos administrativos nảo gozam de independência na autoridade que possuem para interpretarem e aplicarem as leis". O sistema de supremacia dos juízes sobre a Administração teve origem na Grã-Bretanha, a partir do Act of Settlement de 1701. CAETANO, As Garantias..., op. cit., p. 484. 


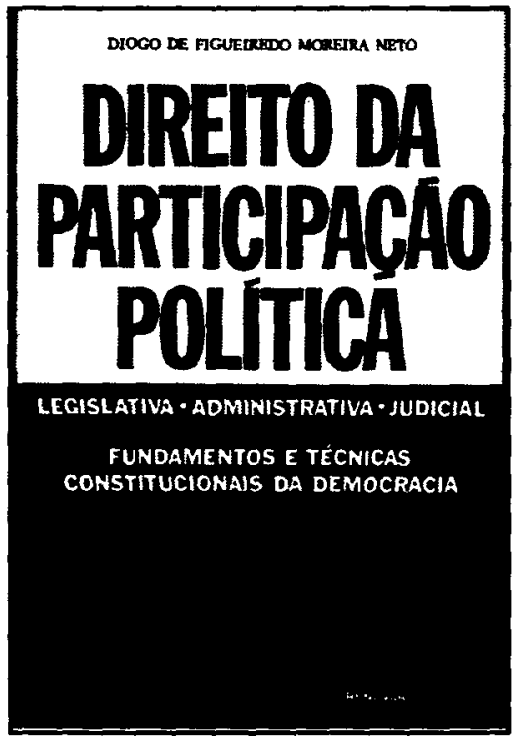

Ref. 0042

Brochura

214 págs.

Form. 14x21

1992

\section{DIREITO \\ DA PARTICIPAÇÃO POLÍTICA}

Diogo de Figueiredo Moreira Neto

Nesta obra o autor dedica notável estudo em que aprofunda, sob todos os ângulos, o tema de participação política e os instrumentos funcionais que lhe são oferecidos. Não se trata de uma obra doutrinária densa e profunda, é também crítica de rumos e possibilidades na exploração dos novos caminhos abertos à participação popular. 